\title{
BAYELSA, IN SEARCH OF A SUSTAINABLE HEALTH FINANCING SCHEME
}

KALADA GODSON MCFUBARA

(Received 19 August 2016; Revision Accepted 8 September 2016)

\begin{abstract}
Background: A sustainable health care financing scheme has been difficult to establish in Bayelsa State. This is evident in the different attempts at fashioning an effective health financing scheme by subsequent governments.

Objectives: This study sought to identify principles that would guide the effective implementation of a health financing scheme.

Method: Methods of health care financing were examined by means of documentary analysis, interviews with programme managers and questionnaire administration to health service users.

Results and analysis: In 2012 budgetary allocation to the State Hospitals Board and the Niger Delta University Teaching Hospital were just $0.15 \%$ and $0.70 \%$ respectively. Before 2000 less than $0.14 \%$ of national budget was allocated to patient care. These meagre allocations were because the same source that funds patient care services also funds health research, capital projects and overhead costs of all health agencies.

Conclusion: Although Bayelsa is a developing state, a sustainable health financing scheme will depend on a health system that allows efficiency in programme management, effectiveness of facilities and workforce professionalism. It is therefore suggested that attention should be given to the health system first because it is there that any sustainable scheme will operate in.
\end{abstract}

KEYWORDS: Healthcare, health financing, health insurance, health policy

\section{INTRODUCTION}

Bayelsa State is over twenty years old yet attempts to provide sustainable health financing scheme has not been successful. The reason is poor funding and this is despite that a major objective of government health policy is to provide health care that is accessible, affordable, kind and free at the point of delivery (Bayelsa State Government, 2000). Safeguarding public health as the policy proposes, presupposes an effective health financing system. A health care financing system refers to a system whereby the allocation of finances to the health sector is convenient for facility users and programme managers and implementers. The allocation could be by government, groups, organizations or individuals. The important thing, according to Albert Calmette, is to know that money spent on safeguarding public health produces wealth because it protects the human capital of the state.

Meanwhile as health care costs keep growing, the proportion of gross national product allocated to the health sector, even at state level, keeps diminishing. For instance, in 2015 the $6 \%$ national budget for health decreased to $4 \%$ in 2016. At the state level in 2014 the $2.74 \%$ state budget for health decreased to $2-24 \%$ in 2015 (Bayelsa State of Nigeria, 2015). This trend which demonstrates the operation of the inverse care law (Hart, 1971) suggests that high quality health care will not be available, affordable or accessible to all. Thus, those who are wealthy and privileged, travel abroad to access effective health care. For governments this can be counter-productive especially when the policy makers are among those involved in this export of health funds. For example, in 2006 the wife of the Speaker of Nigeria's House of Representatives opted to have their baby in a Ghanaian hospital. In the same period the Vice President travelled overseas for a knee surgery. Recently the President was on vacation abroad but also had the plan to be attended to by host nation ENT doctors, may be to confirm that Nigerian ENT doctors really know what they are doing. Nevertheless these can be seen to be happening at the same time that the Governments are talking much about ending medical tourism. To make the point clear, medical tourism is not mainly about travelling to see foreign doctors but essentially about the export of a state's health finances or finances that could have been put into health. That is why for the individuals who cannot travel abroad to access effective health care or confirm the care received at home, they are faced with high health care premium. These premiums are often rejected because they portend a double jeopardy by aligning with unsatisfactory quality of care.

In Nigeria it does not appear that the $75 \%$ of patients who cannot pay from out-of-pocket for their health care bills (Bayelsa State Goverment, 2000) has

Kalada Godson McFubara, Department of Community Medicine, Niger Delta University, Bayelsa State, Nigeria 
fallen. Before 2000 the bills ranged between twenty-one thousand six hundred to twenty-four thousand naira per annum per family, and these have continued to deny the people access to effective health care. In fact the need to put pocket money into health care by families or individuals diminishes the ability to save and also diminishes savings earlier made. This creates a cycle of poverty - poverty of health which leads to poverty of wealth and vice versa. In this study the objectives are to examine various methods of health care financing identify themes to guide a discussion on system principles for effective health care financing.

\section{METHOD OF STUDY}

Bayelsa state with eight local governments is the smallest state in Nigeria. It produces over $40 \%$ of Nigeria's crude oil and is rich in oil and gas. These resources provide the funds to finance social services including health care. The people who are mainly engaged in farming, fishing, palm produce, lumbering, boat carving and weaving, also need effective health care to curb the prevalent communicable and emerging non-communicable diseases. Thus, analysis of records from the Ministries of Health, Budget and Economic Planning, as well as face-to-face interviews with programme managers of the health financing schemes, were carried out. Questionnaire administration to a convenient sample of 198 civil servants, who utilize the state health service, was also conducted. Only civil servants were used because they constituted the bulk of beneficiaries of the first Bayelsa Health Services Scheme (BHSS) and the aim was to identify level of satisfaction with that scheme. Response rate was $61 \%$. The themes identified in the exercise were reviewed so as to relate them to the objective. The exercise lasted for six months.

\section{RESULT AND ANALYSIS}

Methods of health care financing in Nigeria: Five methods of health financing were identified. They are out-of-pocket, taxation, insurance, natural endowment and retaining fee systems. Of these the out-of-pocket and retaining fee methods are mainly private whereas the taxation and natural endowment methods are mainly public. The insurance method can be either private or public or a mixture of both. Until recently and for virtually all State Governments in Nigeria health care financing has been mainly by direct allocation from the federation account. This consists of proceeds from natural resources like petroleum (major) and taxation (minor). In Bayelsa State internally generated revenue (IGR) which comes mainly from taxation (value-added and personal income taxes) has not been significant. According to the Governor of the state (Dickson, 2015) the IGR has only recently begun to rise from less than 100 million naira monthly in 2011 to about one billion naira monthly in 2014. Individual health care financing comes direct from out-of-pocket. Other health finances such as those of private and public corporate organisations come from employers or by a system of health insurance. For some time now, health financing by insurance is receiving the acceptance of the public in Nigeria.

State health budgetary allocations: Table 1 below shows State financial allocations to the Ministry of Health over a period of eight years. During the period 2008 -2015 both recurrent and capital expenditure ranged from $1.5-8 \%$ and $2.7-7.9 \%$ respectively of the total revenue of the state. Among the several items that constitute budget items, only a few like construction/renovation of health facilities, provision of equipment, drugs and medical consumables, operation of programmes such as the Bayelsa Medical Emergency Service and Medical Diagnostic Centre, have direct impact on patient care and these receive very meagre percentage values of the total revenue. In 2012 for instance, the Bayelsa State Hospitals Management Board and the Niger Delta University Teaching Hospital received from the Government budgetary allocations of $0.15 \%$ and $0.70 \%$ respectively. This means that whether at the ministry or agency level the amount of money that goes into patient care is far too low when examined in the light of the $15 \%$ of national budget recommended by African leaders in Abuja 2001(Bayelsa State of Nigeria, 2010).

Table 1: Bayelsa State budget allocations to the Ministry of Health 2008 - 2015.

\begin{tabular}{|lll|}
\hline Budget Year & Recurrent (N) & Capital (N) \\
\hline $\mathbf{2 0 0 8}$ & $3,379,410,657.00$ & $6,950,574,000.00$ \\
& $(5.25 \%)$ & $(5.6 \%)$ \\
2009 & $4,888,152,646.00$ & $9,717,000,000.00$ \\
& $(7.6 \%)$ & $(7.9 \%)$ \\
2010 & $5,084,250,114.00$ & $3,792,531,606.73$ \\
& $(4.26 \%)$ & $(5.6 \%)$ \\
2011 & $5,304,250,114.00$ & $7,274,314,153.70$ \\
& $(5.82 \%)$ & $(7.1 \%)$ \\
2012 & $7,979,168,100.00$ & $8,196,000,000.00$ \\
& $(8.34 \%)$ & $(5.75 \%)$ \\
2013 & $7,499,529,887.00$ & $6,900,600,000.00$ \\
2014 & $(5.29 \%)$ & $(4.26 \%)$ \\
& $2,504,462,052.00$ & $5,679,268,500.00$ \\
2015 & $(1.54 \%)$ & $(4.15 \%)$ \\
& $3,280,834,505.00$ & $3,893,258,565.00$ \\
& $(1.87 \%)$ & $(2.69 \%)$ \\
\hline
\end{tabular}


The Bayelsa Health Services Scheme (BHSS Mark 1): Bayelsa State introduced the BHSS in 2001. It was a health care financing scheme designed to provide top quality health services to the people. In operation it had a semblance of the National Health Insurance Scheme (NHIS) but was adapted to suit the terrain and financial capabilities of the people of Bayelsa State. The philosophy was that of being a brother's keeper and it was fashioned to be implemented at the primary, secondary and tertiary levels of care. The state and local governments, corporate bodies and residents of the state are stakeholders. The scheme started with the formal sector and it was compulsory in that premium was deducted at salary source. In a face-to-face interview conducted with the Programme Manager (PM) it was found that in less than three years of its take-off over six thousand persons had registered with the scheme. This was made up of 3,824 civil servants and 3,199 others who paid cash to the scheme. By 2006 civil servants deductions of two hundred naira per staff and the contributions of others on a monthly basis was 2.6 million naira. This shows an increase of contributors and the reason being an increased level of awareness as well as improved quality of service.

Table 2: Activity performance of the BHSS as at March 2003

\begin{tabular}{|lll|}
\hline S/N & Item description & Quantity \\
\hline 1 & Heath facilities designated for BHSS & 53 (before February it was \\
2 & Civil servants registered as at December & 30 ) \\
2,824 \\
& 2002 & \\
3 & Others (paid by cash into the scheme) & 3,199 \\
4 & Number of cases treated & 25,585 \\
5 & major cases - fibroid & 92 \\
6 & Minor cases - hernia & 75 \\
7 & Other minor cases & 87 \\
8 & Delivery cases & 91 \\
9 & Laboratory services cases $\quad$ (including & 1,324 \\
10 & Ophthalmological cal & \\
& glasses) & \\
\hline
\end{tabular}

The Scheme was however bedevilled with some challenges including irregular funding from Government. For instance, at its take-off the State Government provided 20 million naira monthly for over one year. Thereafter the amount was reduced to 10 million naira monthly. This however was not regularly released. Meanwhile it was estimated that with 400,000 contributors in the scheme in their different categories, it would require fifty-five million naira to be implemented. But this was not realised in the short time of its implementation. Another problem of the scheme was the N 480,000.00 monthly fixed capitation demanded by the private medical practitioners whereas Government was offering $N$ 180,000.00. It would be noted that at inception the BHSS had the private practitioners involved. But they severed relationship when Government failed to pay the N 480,000.00 demanded by them. The other challenge for the scheme was that in less than three years of its introduction the scheme had three managers. A more difficult problem was that primary health care, the care upon which government policy is hinged, is not properly implemented in the state. Despite these challenges BHSS was still found to be successful because before it was introduced satisfaction with public health services was $47 \%$ but with introduction of the scheme user satisfaction rose to $56 \%$ (table 3). 
Table 3: User opinion of state health service before and after the BHSS

\begin{tabular}{|c|c|c|c|c|c|c|}
\hline \multirow[t]{2}{*}{ Service description } & \multicolumn{6}{|c|}{ Frequency of use/satisfaction with usage $(\mathrm{N}=121)$} \\
\hline & V Frequently & Frequently & Infrequently & V. Infrequently & No idea & No response \\
\hline $\begin{array}{l}\text { Use of public health } \\
\text { service before BHSS }\end{array}$ & $4(3 \%)$ & $16(13.2 \%)$ & $66(55)$ & $30(25 \%)$ & $4(3 \%)$ & $1(0.8 \%)$ \\
\hline $\begin{array}{l}\text { Use of public health } \\
\text { service in the BHSS }\end{array}$ & $8(6.6 \%)$ & $21(17.4 \%)$ & $58(48 \%)$ & $25(21 \%)$ & $9(7.4 \%)$ & --- \\
\hline Service description & V. Satisfied & Satisfied & Unsatisfied & V. Unsatisfied & No idea & No response \\
\hline $\begin{array}{l}\text { Satisfaction with health } \\
\text { service before the } \\
\text { BHSS }\end{array}$ & $8(6.6 \%)$ & 49 (40.5\%) & 40 (33.1\%) & $9(7.4 \%)$ & $15(12.4 \%)$ & ---- \\
\hline $\begin{array}{l}\text { Satisfaction with health } \\
\text { service in the BHSS }\end{array}$ & $12(10 \%)$ & $56(46 \%)$ & $28(23 \%)$ & $8(7 \%)$ & $11(9 \%)$ & $6(5 \%)$ \\
\hline Service description & Yes & No & No idea & No response & --- & --- \\
\hline BHSS premium OK? & $103(85.1 \%)$ & $8(6.6 \%)$ & $9(7.4 \%)$ & $1(0.8 \%)$ & --- & --- \\
\hline Service description & $\begin{array}{l}\text { Increase } \\
\text { service }\end{array}$ & $\begin{array}{l}\text { Reduce } \\
\text { service }\end{array}$ & Retain service & No idea & No response & --- \\
\hline $\begin{array}{l}\text { Change to BHSS } \\
\text { premium }\end{array}$ & $1(0.8 \%)$ & $25(20.7 \%)$ & $92(76 \%)$ & $3(2.5)$ & -- & --- \\
\hline Service description & Low & High & & No idea & No response & \\
\hline $\begin{array}{lcr}\text { Quality } & \text { of } & \text { service } \\
\text { linked } & \text { to } & \text { desired } \\
\text { change } & & \end{array}$ & $42(34.7 \%)$ & $2(1.7 \%)$ & $69(57 \%)$ & $8(6.6 \%)$ & --- & --- \\
\hline Service description & Yes & & No idea & No response & & \\
\hline $\begin{array}{l}\text { More services in the } \\
\text { BHSS }\end{array}$ & $85(70.2 \%)$ & $25(20.7 \%)$ & $11(9 \%)$ & --- & --- & --- \\
\hline $\begin{array}{l}\text { More services with } \\
\text { higher premium }\end{array}$ & $34(28.1 \%)$ & $81(67 \%)$ & $5(4.1 \%)$ & $1(0.8 \%)$ & --- & --- \\
\hline
\end{tabular}

The Bayelsa Medicare Scheme (BMS): When a new administration came into office in 2007 it rebranded BHSS Mark 1 to BMS (Brisibe, 2011). The BMS was however, to be more expensive as it categorised contributors into standard $(1,000.00$ naira), Premium $(5,000.00$ naira) and gold (10,000.00 naira) policy holders. Also in the pilot phase the BMS had only higher order health facilities without lower order facility base. This gave the scheme the picture of a building without foundation. Thus the failure to take lower order facilities (primary health centres) into consideration at the onset meant that within the state (national) health policy the BMS had no base to effectively operate from. Hence the scheme collapsed even before it could stand.

A New BHSS (BHSS Mark 2): In March 2013 the new administration of Governor Henry Seriake Dickson inaugurated a 24-member committee called the Bayelsa Health Insurance Policy Formulation Committee (BHIPFC) with the following terms of reference (Bayelsa Health Insurance Policy Committee, 2013);

1. To articulate a comprehensive health insurance policy/scheme for Bayelsa State

2. To recommend appropriate governance structure for effective delivery of health insurance
3. To recommend scope of health services to be delivered/covered by the scheme

4. To recommend terms and conditions for subscription by prospective subscribers

5. To undertake other things to make the scheme efficient and of international standard.

The Committee after inauguration had a stakeholders' workshop where different Health Maintenance Organisations (HMOs) made presentations. By early April 2013 the Committee formed smaller groups that visited various communities in the state to ascertain those that did not have health facilities. The BHIPFC also visited states that implemented health insurance scheme like Cross River and Lagos as well as headquarter of the NHIS in Abuja. The Committee had a wide consultation and did a thorough review of literature on health insurance in developed countries. In its recommendations two models of implementing a health insurance scheme were described. This study however found that the models were not actually different from the ones earlier tried. For instance Model 2 had contributions graded by level of position of the workers in the formal sector of the economy. Model 1 was similar to both the NHIS and the BMS. These are shown in table 4 below. 
Table 4.i: Model 1 or BHSS Mark 2. This can also be described as pay as you rise (formal sector): It comprises a fixed rate of contribution across board as shown:

Employee, $5 \%$ basic salary or $1.75 \%$ consolidated salary

Employer, $10 \%$ basic salary of the employee or $3.5 \%$ of consolidated salary of employee

Informal sector premium was yet to be determined at the time o this study.

Vulnerable group, $100 \%$ subsidised by government.

Table 4.ii: Model 2 or Pay as you lie (formal and informal sectors)

\begin{tabular}{|c|c|c|}
\hline Class of contributor & abingate & $\begin{array}{l}\text { Proposed } \\
\text { monthly } \\
\text { contributio } \\
n \text { in Naira } \\
\text { (N) }\end{array}$ \\
\hline Civil servants on Grade levels & $1-6$ & 500.00 \\
\hline Civil servants on Grade levels & $7-13$ & $1,000.00$ \\
\hline Permanent Secretary/Political office holders & $14 \cdot 17+$ & $2,500.00$ \\
\hline Organised private employee & ...-... & $2,000.00$ \\
\hline Organised private employer & ...-... & $2,000.00$ \\
\hline I $n d i v i d u$ a $\mid s$ & -..-- & $2,000.00$ \\
\hline Urban self-employed & ...-...- & $1,000.00$ \\
\hline Ruraldwellers & $\ldots$ & $5,000.00$ \\
\hline Vulnerable group (children < 5years, & $-\cdots--$ & $F R E E$ \\
\hline $\begin{array}{l}\text { Pregnant women, physically- } \\
\text { challenged persons, pensiont } \\
\text { the elderly }-65 \text { years }+ \text { ) }\end{array}$ & & \\
\hline $\begin{array}{lllll} & t & a & t & e\end{array}$ & $\ldots$ & $100,000,000.00$ \\
\hline 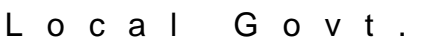 & ........ & $3,000,000.00$ \\
\hline
\end{tabular}

Health Facility status: An NTA documentary, Week End File, of February 16, 2013 showed that the state of health facilities, especially primary health care facilities in the country is similar to what is found in Bayelsa state. For instance, analysis of the findings of the 2013 BHIPF committee shows that at Oluasiri in Nembe Local Government Area (LGA) a cottage hospital built by Shell $\mathrm{BP}$ was found to be locked up because there were no working materials. In Otunwama also in Nembe LGA a World Bank assisted health centre was in dilapidated condition. In Yenagoa, the State capital as well as the headquarter of Yenagoa Local Government Area, of 29 health centres only few were found to be functioning at maximum capacity and these are not equitably distributed. Residents of Ewoama in Brass LGA can be spared the inconvenience of the turbulent Brass River if they were provided with a health facility. In Olobiri and Otoni-gbene in Kolokuma/Opokuma LGA though they have primary schools, there were no health facilities. For these two communities to access a health facility one would spend 40 minutes and 90 minutes respectively by boat. For the residents of Igbedi in the same LGA it is a three-hour journey by boat to reach a health facility at Sabagreia. In their conclusions the sub committees of the BHIPFC recommended different types of health facilities but mainly PHC services for the various communities. Considering all the difficulties above the BHIPFC recommended that Bayelsa State should develop its own health financing (insurance) scheme.

\section{DISCUSSION}

The development of public health financing: Public health financing is a development from the private sector. In Nigeria this can be traced to the religious and voluntary organisations such as the Catholic Mission and Church Missionary Society. Professor Akin Osinbogun in as NTA interview of 2008 indicated that in the nineteen seventies his team (a community voluntary team) in the west, also started a community health insurance project. But unlike the type introduced by the religious organisations that by Osibogun team had the direct input of members in the management of the funds. It was a means of pooling resources and sharing risks with each other in the community. In 2001 during the public hearing on the NHIS in Nigeria a report by the House Committee on Health indicated that there was a preponderance of opinion for the adoption of a universal insurance coverage (Ogbeide, 2001). In fact, community-oriented voluntary system of financing social services has contributed greatly to the development of public/state) social services. Thus public health financing can be seen as the demonstration of the communitarian principle of mutual responsibility (Tam, 1998).

In the United States of America at inception public health financing was a social enterprise run by voluntary sector organizations like the Blue Shield, Blue Cross, Kaiser and Permanent Health Plan. These 
organizations charged some premium on everyone who was able in the community. It was such that the young and healthy subsidised for the old and sick. That system later gave way to a system run by profit insurance companies whose policies charged less for less users (Fuchs, V. R.,) thereby discarding the community-wide insurance system. Until the development of Obama care this may explain why the United States of America continued to have several millions of people uninsured for their health care. On the other hand in Great Britain it was the 1911 National Health Insurance Act that marked a major step in the development of public health financing in that country. The Act provided for free care for low income earners even though contribution was by all workers, the state and the employers (Ham, 1982).

BHIPFC recommendation and the BHSS Mark1: Although the BHIPFC observed that the NHIS had its own problems hence it has been difficult for most states in Nigeria to key into the scheme, report (Bayelsa State Ministry of Health, 2013) shows that Cross River and Bauchi had already keyed into the NHIS. Other states like Rivers and Akwa lbom had also expressed interest to key into the scheme. Bayelsa Health Insurance Policy Formulation Committee has attributed the difficulty in keying into the NHIS to the fact that most communities in the State had no health facilities. Moreover those communities that had facilities, such facilities were not purposely built or they lacked equipment. For instance, $\mathrm{BHIPHC}$ found that most of the available facilities were operated in town halls, rented apartments and private houses. These conditions made most of them nonfunctional.

Despite the problems in the BHSS Mark 1, it was doing well up to 2007. This attracted States like Kaduna, Plateau, Zamfara, Edo, Katsina, Abuja, FMoH and the NHIS itself to study the operations of the scheme. Although the Committee (BHIPFC) described Model 2 as not a substitute for model 1 because Model 1 is like a welfare scheme, Model 2 the Committee's preferred model, puts an officer on grade level 1 (the least grade) who pays $\mathrm{N} 500.00$ of monthly basic salary at a disadvantage. This is because that officer will be contributing $2.7 \%$ of that same basic salary $(\mathrm{N18,000.00)}$ when compared with the $2.5 \%(\mathrm{~N} 2,500.00)$ contribution by an officer on grade level 14 (basic salary at least N100,000.00 ). It therefore means that the higher one is on the salary grade level in Model 2 the lower the rate of contribution one makes. Even so, Model 1 cannot be a welfare scheme for everybody considering that contributors would be paying for the services they are to receive. It may be subsidised and also seen as a welfare scheme for the vulnerable group but it cannot be considered a welfare scheme for everybody. For instance, a civil servant on a monthly minimum wage in Nigeria of $\mathbf{N 1 8 , 0 0 0 . 0 0}$ naira will be paying $\mathbf{N} 900.00$ which is even higher than the $\$ 500.00$ naira monthly in Model 2. In fact, for Model 1 the percentage contributions are on a high scale and may need to be reviewed. A rate of $2.5 \%$ for grade levels $1-12$ and $5 \%$ for grade levels 13-17 can be considered as it would still provide more funds when compared to BHSS Mark 1 to ensure sustainability of the scheme. For purposes of efficiency it can also be considered as a modified form of NHIS. Therefore considering the difficulties that have shown in establishing a health financing scheme in Nigeria, a primary duty should be the identification and description of principles to guide the implementation of any new scheme.

Principles for efficient health care financing: Although in the two models that the Bayelsa Health Insurance Policy Committee recommended one sees higher premiums than that of BHSS Mark 1, McFubara et al. (2012) had reported the people's willingness to pay for their health through an insurance scheme. But the people must be shown the value for what they are contributing. This would mean that for effective health care in the context of health financing the three basic components (tripod stand) of the health system vis-a-viz the health programme or scheme to be operated, the facilities for implementing the scheme and the workforce to operate the scheme, must be taken into consideration. To do this the tripod must be seen to be supportive of the health system in the following manner.

Programme efficiency: BHSS Mark I suffered from programme inefficiency in that, firstly, not all available public health facilities and units were involved in the implementation. This is because most of the available facilities and units were not well-equipped. For instance, the customer care unit of the scheme had no vehicle with a public address system. This affected the initial public awareness of the scheme. Secondly, the scheme's Manager who is also the Chief Executive Officer of the scheme was not a signatory to the Scheme's accounting system. It is therefore suggested that in exercising supervisory role over any department or agency of the state, the supervising Ministry or department should ensure that managerial rules of engagement (Davies, 2001) are allowed to operate. The reason is that health is not only the business of doctors and nurses but also that of health care managers. The degree of freedom allowed for internal programme management can enhance the efficiency of a programme.

Facility effectiveness: As shown in the reports of the BHIPFC subcommittees, most communities had no facilities. In communities where facilities were available they either had no equipment or no maintenance for the equipment that was there. Moreover since primary health care is the cornerstone of the state's health policy, the availability of well-equipped centres must be seen as sine qua non for facility effectiveness. A well-equipped facility does not necessarily mean that it must have state-of-the-art technological materials. However the facilities must be seen to provide essential health care that is acceptable to the people and with their involvement. Thus for primary health centres appropriate locally improvised materials with trained personnel can provide services needed in an effective manner. For instance, if a community has a school with wellfurnished first aid centre it can serve the purpose of a primary health care facility for the school and its host community. After all, a health promoting school is expected to serve learners, teachers, administrators and 
others within the school community. The same thing can apply to facilities at the other levels of health care.

Workforce professionalism: The health system consists of multiple key professions. Although the level of manpower among these professions is low (McFubara et al., 2012) there are three health personnel training institutions in the state. Even so, it does not appear that the institutions are adequately inculcating virtues of professionalism in the trainees. Thus professional dominance and rivalry which McFubara (2014) has reported as retrogressive have also become endemic to the health system in Nigeria. Elimination of these is essential for efficiency and effectiveness in the health system. Health services being essential service require the specific skills of all professionals operating within the health system and for them to show high sense of professionalism in the discharge of their duties. By so doing they will allow corporatism and give freedom of service to all including health programme managers.

\section{CONCLUSION}

In this paper it is shown that despite that public health financing developed from the private non-state sector, the public sector has not been able to effectively implement a sustainable health financing scheme. This is because the health system itself has not been established on principles of sustainable development. Hence even though the out-of-pocket method of payment for health care and services has been a major source of financing patient care in Nigeria and the BHSS having been tried, they have not shown to be sustainable. In contrast the Kwara State Health Insurance Programme, which recently won an award for sustainable development (Ndili, 2016), was able to achieve that feat because the programme was fashioned under the principle of qualitative health care. KSHIP is collaboration between Dutch government, private insurance, private foundation and Kwara State government, with the latter in the lead for funding. The paper therefore concluded that because health activities operate within a health system, that system must allow the principles of workforce professionalism, facility effectiveness and programme efficiency to play out appropriately in the activities, including health activities that are conducted in it. Without such allowance no meaningful amount of funding from anywhere can be sustained in the health sector.

\section{REFERENCES}

Bayelsa State Government., 2000. Health Policy. Yenagoa: Ministry of Health, Bayelsa State.

Bayelsa State of Nigeria., Year 2015 and 2014 approved budget, vol 2 .

Bayelsa State Government., The ABC of Bayelsa Health Services Scheme. Yenagoa: Ministry of Health.

Bayelsa State of Nigeria., 2010. State Strategic Health Development Plan 2010 - 2015.
Bayelsa Health Insurance Policy Formulation Committee., 2013. Communities without Health Facilities in Bayelsa. Yenagoa: Ministry of Health.

Bayelsa State Ministry of Health., 2013. Presentations on Health Insurance by Stakeholders/healthcare Financing Models in some Countries and Reports of visits to other states. Yenagoa: Ministry of Health, Office of the Director, PRS.

Brisibe, M., 2011. We have a viable health plan. Bayelsa Health: Our Journey so far. A quarterly publication of the Bayelsa State Ministry of Health, June, 2, (1): 11.

Davies, J., 2001. Rules of engagement. Health Services Journal 20 September 22-25.

Dickson, H. S., 2015. Appropriation Bill Estimates of Bayelsa State presented by the Governor to the State House of Assembly on the $14^{\text {th }}$ of November 2014.

Fuchs, V. R., What's Ahead for Health Insurance in the U. S? New England Journal of Medicine. 346, (23): $1822-1824$.

Ham, C., 1982. Health Policy in Britain. The Politics and Organization of the Health Service, 3rd edition. London: MacMillan p. 10.

Hart, J. T., 1971. The Inverse Care Law. The Lancet, 405-412.

McFubara, K. G., 2014. Professional rivalry and patient safety in Nigeria. IHSAN journal, vol. 18 No 1 December, 35-40.

McFubara, K. G., Edoni, E. E and Ezonbodo-Akwagbe, R. E., 2012. Health Manpower Development in Bayelsa State, Nigeria. Risk Management and Health Policy, 5:127-135.

McFubara, K. G., Owoeye, G. O and Richard, G., 2011. The NHIS in a Niger Delta Community: Knowledge, Attitude and Practice. IHSAN Journal, 15, (1): 10-16.

Ndili, N., 2016. Kwara State Health Insurance Programme win FT/IFC transformational Business Award for Achievement in Sustainable Development. THISDAY 23 June www.thisdaylive.com/index.php/2016/6

Ogbeide, W., 2001. Equity in Healthcare Service Delivery through the NHIS: A Pillar of an Enduring Democracy. Journal of the Institute of Health Services Administrators of Nigeria, vol. 6 , (2): 6-10.

Tam, H., 1998. Communitarianism: A New Agenda for Politics and Citizenship. London: MacMillan. 
